\title{
CHILLING EFFECT ON SOLUBLE SUGARS, RESPIRATION RATE, TOTAL PHENOLICS, PEROXIDASE ACTIVITY AND DORMANCY OF ONION BULBS
}

\author{
Noureddine Benkeblia*; Norio Shiomi \\ Department of Food and Nutrition Sciences, Graduate School of Dairy Science Research, Rakuno Gakuen University, \\ 582 Bunkyodai Midorimachi, Ebetsu, Hokkaido, 069-8501, Japan \\ *Corresponding author <ben-nour@rakuno.ac.jp>
}

ABSTRACT: Besides onions being one of the most cultivated and consumed vegetables, during storage onion bulbs are still affected by many physiological, biochemical and technological factors which can influence their quality. Respiration rate $\left(\mathrm{RR}_{\mathrm{O} 2}\right)$, soluble sugars (SS), total phenolics (TP), and peroxidase (POD) activity were measured in inner bud tissues during a dormancy break of onion bulbs treated four weeks at $0^{\circ} \mathrm{C}$ and stored in the dark at $20^{\circ} \mathrm{C}$. Control bulbs were stored simultaneously in the same condition. Breakage of dormancy was checked by the appearance of first green internal leaves by cutting longitudinally 30 bulbs. After eight weeks, $R R_{O 2}$ of sprouted onions was $52 \%$ higher than that of freshly harvested and dormant bulbs. One week after cooling SS decreased from 15 to $9 \mathrm{mg} \mathrm{g}^{-1}$ fresh weight, and then peaked from 9 to $19 \mathrm{mg} \mathrm{g}^{-1}$ after three weeks. For control bulbs, a similar peak was observed after six weeks. For inner buds of cold-treated onions, a slight increase of TP (from 0.17 to $0.2 \mathrm{mg} \mathrm{g}^{-1}$; fresh weight) was observed during the first two weeks of cooling, and then a decrease to $0.11 \mathrm{mg} \mathrm{g}^{-1}$ was observed after eight weeks. For inner buds of control bulbs, TP also increased slightly from 0.17 to $0.2 \mathrm{mg} \mathrm{g}^{-1}$ after five weeks, and decreased to $0.15 \mathrm{mg} \mathrm{g}^{-1}$ after seven weeks when bulbs began to sprout. POD activity showed a similar pattern in relation to TP. For cold-treated bulbs, POD activity increased to $1.7 \mathrm{U} \mathrm{g}^{-1}$ fresh weight after two weeks, and decreased to $1.1 \mathrm{U} \mathrm{g}^{-1}$ during the last four weeks. For control samples, POD activity was stable during 4 weeks and decreased progressively by $29 \%$ during the last four weeks. This decrease in POD activity coincided with the decrease in TP, and coincided with onset of sprouting. With cold treatment, first sprouts were observed during the third week, while total sprouting was observed after eight weeks. In comparison, only $20 \%$ of the control bulbs sprouted after the period of 8 weeks. Key words: $\mathrm{O}_{2}$ consumption, saccharides, phenolics, peroxidase, sprouting

\section{EFEITO DO RESFRIAMENTO SOBRE AÇÚCARES SOLÚVEIS, TAXA DE RESPIRAÇÃO, FENÓIS TOTAIS, ATIVIDADE DE PEROXIDASE E DORMÊNCIA DE BULBOS DE CEBOLA}

RESUMO: Além de ser uma das hortaliças mais cultivada e consumida, bulbos de cebola são afetados, durante a armazenagem, por fatores fisiológicos, bioquímicos e tecnológicos, que podem afetar seus atributos de qualidade. Taxa de respiração $\left(\mathrm{RR}_{\mathrm{O} 2}\right)$, açucares solúveis (SS), fenóis totais (TP) e atividade de peroxidase (POD) foram medidos em tecidos internos de brotos, durante uma quebra de dormência de bulbos de cebola, tratados por quatro semanas a $0^{\circ} \mathrm{C}$ e armazenados no escuro a $20^{\circ} \mathrm{C}$. Bulbos controle foram armazenados simultaneamente na mesma condição. A quebra da dormência foi verificada através do aparecimento das primeiras folhas internas verdes, cortando 30 bulbos longitudinalmente. Depois de oito semanas a $\mathrm{RR}_{\mathrm{O} 2}$ de bulbos brotados foi $52 \%$ maior em relação a bulbos recentemente colhidos e bulbos dormentes. Os SS diminuíram uma semana após resfriamento, de 15 para $9 \mathrm{mg} \mathrm{g}^{-1}$ de peso fresco e depois apresentaram um pico, de 9 para $19 \mathrm{mg} \mathrm{g}^{-1}$ depois de três semanas. Para os bulbos controle também foi observado um pico similar depois de seis semanas. Para os brotos internos

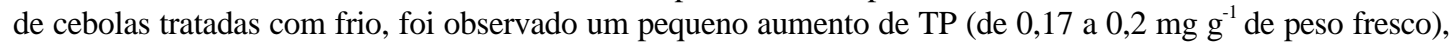

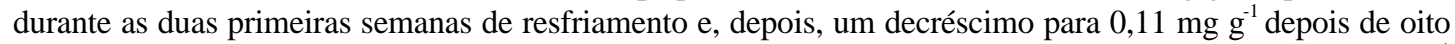
semanas. Para os brotos internos de bulbos controle, os TP também aumentaram pouco, de 0,17 para 0,2 $\mathrm{mg} \mathrm{g}^{-1}$ depois de cinco semanas, decrescendo para $0,15 \mathrm{mg} \mathrm{g}^{-1}$ depois de sete semanas, quando começaram a brotar. A atividade de POD apresentou uma tendência similar em relação aos TP. Para bulbos tratados a frio, a atividade POD aumentou para 1,7 $\mathrm{U} \mathrm{g}^{-1}$ de peso fresco depois de duas semanas, decrescendo para $1,1 \mathrm{U} \mathrm{g}^{-1}$ durante as últimas quatro semanas. Para as amostras controle, a atividade POD permaneceu estável por quatro semanas e decresceu progressivamente de $29 \%$ durante as últimas quatro semanas. O decréscimo da atividade de POD coincidiu com o decréscimo de TP e coincidiu com o início da brotação. Com o tratamento frio, os primeiros brotos foram observados durante a terceira semana, enquanto o brotamento total se deu depois de oito semanas. Em comparação, apenas $20 \%$ dos bulbos controle brotaram depois de oito semanas.

Palavras-chave: consumo de $\mathrm{O}^{2}$, sacarídeos, fenóis, peroxidase, brotamento

Sci. Agric. (Piracicaba, Braz.), v.61, n.3, p.281-285, May/June 2004 


\section{INTRODUCTION}

Onion (Allium cepa L.) has played important role in culinary, as well as in dietary, medicinal and religious roles for centuries. It may be one of the first cultivated crops because of its growing versatility and portability, and can be dried and preserved for long periods. However, during storage, onion bulbs are exposed to environmental and atmospheric conditions which can affect their physiology and biochemistry. During this period, high catabolism is considered the main cause of changes in qualities such as sprouting and rotting (Benkeblia, 2003).

Dormancy of bulbs has major impact on their storage. One of the most popular approaches in the study of dormancy has been to study its physiological basis in sprouts during subsequent exposure to rest-breaking treatments at low temperature (Benkeblia \& Selselet-Attou, 1999; Dennis, 1987). The resting period disappears progressively with time at all storage temperatures, but does so more quickly at some low temperatures than others (Abdallah \& Mann, 1963; Benkeblia \& Selselet-Attou, 1999). Gradual changes in the biochemistry of the bulbs throughout the dormancy period were observed, and low temperatures caused compositional and physiological changes in tissues (Benkeblia et al., 2002; Benkeblia et al., 2000; Benkeblia \& Selselet-Attou, 1999).

Sugar metabolism is closely linked to onion bulb dormancy (Kato, 1966), and the most important biochemical changes occurring during long term storage of vegetables are the quantitative changes in carbohydrates (Rutherford, 1981). Nevertheless, no data are available on the variation of these components during the break of dormancy, particularly under low temperatures. Phenolic compounds and peroxidase are known to play important roles in the ripening and senescence of plants (Harborne, 1994; Greppin et al., 1986). Despite of the large literature available on these aspects, little is known on the biochemical changes occurring during the breakage of dormancy in bulbs (De Hertogh \& Le Nard, 1993; Benkeblia \& Selselet-Attou, 1999) and tubers (Cvirkova et al., 1994), and the involvement of phenolics and peroxidase in the dormancy process and sprouting of onions remains unclear. The present study was carried out to investigate the effects of low temperature $\left(0^{\circ} \mathrm{C}\right)$ on the dormancy break of onion bulbs and biochemical changes in inner bud sprouts.

\section{MATERIAL AND METHODS}

\section{Plant material}

Onion bulbs cv. Rouge Amposta, organic product, free of preharvest chemical treatments, cultivated in the Cavaillon area, Vaucluse, France, freshly harvested and dried in the field for two weeks, were obtained from a local farmer, sorted for uniformity and absence of defects, packed in commercial, 12-Kg plastic (PVC) trays, and placed at $18^{\circ} \mathrm{C}$ prior to the cooling.

\section{Cooling and storage}

Onion bulbs were kept at $0^{\circ} \mathrm{C}$ in the dark during four weeks and then transferred in dark to the $20^{\circ} \mathrm{C}$ and $65 \%$ relative humidity condition. Sprouting was counted starting from the first week of cold treatment. Thirty bulbs were cut longitudinally twice a week to check for sprouting (appearance of first green internal leaves); soluble sugars, total phenolics and peroxidase were assayed simultaneously.

\section{Respiration rate determination}

Respiration rate $\left(\mathrm{RR}_{\mathrm{O} 2}\right)$ was determined on whole onions kept 8 weeks at $20^{\circ} \mathrm{C}$ and without any cold treatment, by the glass jar technique (Benkeblia et al., 2000). Gas samples $(50 \mu \mathrm{L})$ were taken after $1,2,3,4$ and 5 hours through a silicon septum and analyzed by gas chromatograph (model M200, MTI, Fremont, USA). RR $_{\mathrm{O} 2}$ was calculated by linear regression from $\mathrm{O}_{2}$ depletion curve and expressed as mmol kg $\mathrm{h}^{-1}$. The mean value of respiration rate was determined from triplicate measurements.

\section{Soluble sugars analysis}

Soluble sugars (SS) (glucose, fructose, and sucrose) contents were determined by HPLC. Samples $(5 \mathrm{~g})$ of freeze-dried inner bud tissues were homogenized in $50 \mathrm{~mL}$ of water, heated for $30 \mathrm{~min}$ in boiling water bath and centrifuged for $15 \mathrm{~min}$ at 25,000 $\mathrm{g}$. The supernatant was passed through a $0.25 \mu \mathrm{m}$ Millipore filter prior to injection. Sugars were separated by HPLC using a Varian 5000 model (Vista, 5000 series, Les Ulis, France) fitted with a Polyspher CH-CA column $(300 \times 7.8 \mathrm{~mm}$. Merck, Darmstadt, Germany) set at $80^{\circ} \mathrm{C}$ and a differential refractometer detector (Knauer, GmbH, Berlin, Germany). The mobile phase was DDI water at a flow rate of $0.5 \mathrm{~mL} \mathrm{~min}{ }^{-1}$. Sugars were identified and quantified by comparison with authentic sugar samples (Sigma, St Louis, MO, USA).

\section{Total phenolics quantification}

Total phenolics (TP) were extracted by the method described by Brenes et al. (1992), and determined by Folin-Ciocalteu reagent. Samples $(10 \mathrm{~g})$ of inner bud fresh tissues were mixed with $80 \mathrm{~mL}$ aqueous $\mathrm{EtOH}$ (80\%) and $20 \mathrm{~mL}$ of metabisulphite $(25 \mathrm{mmol})$, homogenized for $30 \mathrm{~s}$ and left for $15 \mathrm{~min}$ at $4^{\circ} \mathrm{C}$. The homogenate was filtered and the filtrate used for phenolic determination. Total phenolics were quantified colorimetrically at $730 \mathrm{~nm}$. The standard curve was plotted using chlorogenic acid (Sigma, St Louis, MO, USA) as standard. Total phenolics were expressed as chlorogenic acid equivalent. 


\section{Peroxidase activity assay}

Peroxidase (POD) activity was extracted and assayed according to the method of Günes \& Bayindirli (1993). Inner bud fresh tissues $(10 \mathrm{~g})$ were mixed with $50 \mathrm{~mL}$ of phosphate buffer $\left(60 \mathrm{mmol} \mathrm{L}^{-1}, \mathrm{pH} \mathrm{7.0}\right)$ and blended for $5 \mathrm{~min}$ in blender at minimal speed. The homogenate was centrifuged for $15 \mathrm{~min}$ at $20000 \times \mathrm{g}$ and the supernatant removed for POD activity assay. One $\mathrm{mL}$ of extract was mixed with $1 \mathrm{~mL}$ of guaiacol $\left(45 \mathrm{mmol} \mathrm{L}^{-1}\right), 1 \mathrm{~mL}$ of $\mathrm{H}_{2} \mathrm{O}_{2}\left(200 \mathrm{mmol} \mathrm{L}^{-1}\right)$ and $18 \mathrm{~mL}$ of phosphate buffer $\left(65 \mathrm{mmol} \mathrm{L}^{-1}, \mathrm{pH} 6.5\right)$. After incubation at room temperature for $10 \mathrm{~min}$, absorbance was measured at $430 \mathrm{~nm}$. One unit of the enzyme activity was defined as change in absorbance of $0.001 \mathrm{~min}^{-1}$.

\section{Statistical analysis}

All determinations were carried out in triplicate and expressed on a fresh weight basis. The experiment was repeated twice and data compared by the Student ttest using Statistica 5.0 software.

\section{RESULTS AND DISCUSSION}

Comparatively to respiration of freshly harvested bulbs, $\mathrm{RR}_{\mathrm{O} 2}$ of sprouted onions increased from 0.21 to $0.32 \mathrm{mmol} \mathrm{O}_{2} \mathrm{~kg}^{-1} \mathrm{~h}^{-1}$ after 8 weeks at $20^{\circ} \mathrm{C}$ (Figure 1). The average rate of increase in respiration was determined by fitting a linear regression line to the respiration rate vs time (data not shown), and was $14 \mu \mathrm{mol} \mathrm{kg}^{-1} \mathrm{~h}^{-1}$ per week. The increase in the respiration rate is the consequence of physiological changes where this period corresponds to the break of dormancy and the onset of sprouting even if sprouts are not emergent from the necks. This high respiration rate indicates a higher oxygen consumption and an intense metabolic activity mainly carbohydrate catabolism. This result is consistent with the findings of Loogheed \& Franklin (1975) who reported a value of $0.24 \mathrm{mmol} \mathrm{CO} \mathrm{kg}^{-1} \mathrm{~h}^{-1}$ exchange from sprouted onions stored at $21^{\circ} \mathrm{C}$.

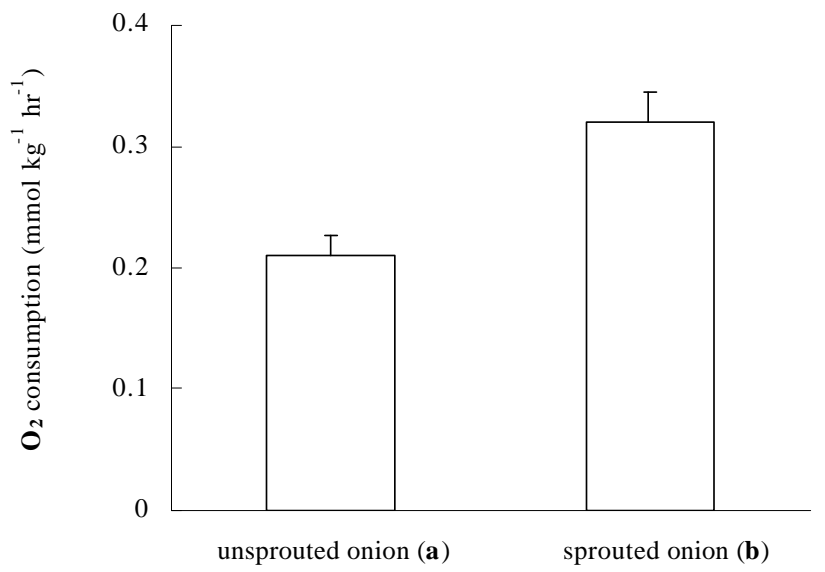

Figure 1 - Effect of the respiration rate of fresh harvested bulbs and bulbs kept at $20^{\circ} \mathrm{C}$ during two months on the breakage of dormancy.
For cold treated bulbs, SS decreased after 1 week (during cold treatment) from 15 to $9 \mathrm{mg} \mathrm{g}^{-1}$ fresh weight, but increased sharply to $19 \mathrm{mg} \mathrm{g}^{-1}$ after three weeks (Figure 2). Then, they decreased to $5 \mathrm{mg}$ and varied from 5 to $7 \mathrm{mg} \mathrm{g}^{-1}$ fresh weight during the last three weeks. For control samples, SS content increased from 15 to $17 \mathrm{mg} \mathrm{g}^{-1}$ fresh weight during the five first weeks, then peaked to $22 \mathrm{mg} \mathrm{g}^{-1}$ between the fifth and seventh week period, and then decreased abruptly to $12 \mathrm{mg} \mathrm{g}^{-1}$ during the two last weeks. In both case, peaks coincided with the onset of sprouting. Cold treatment was significant $(P<0.05)$ in relation to the variation of soluble sugars. The rapid increase in SS content observed during cold treatment probably resulted from the low temperature hydrolysis of fructans, the major oligosaccharides in onion bulbs. This accumulation of SS caused by cooling could probably initiate internal sprouting observed after cold treatment. Similar results were reported by Rutherford (1981), however high glucose concentration was noted during this peak (Pak et al., 1995). Hurst et al. (1985) also noted at $4^{\circ} \mathrm{C}$ a rapid increase in percent sugar of onion between four and eight weeks.

During the first two weeks, TP in the inner bud of cold-treated bulbs increased to $0.2 \mathrm{mg} \mathrm{g}^{-1}$ fresh weight. Then, decreased abruptly to $0.13 \mathrm{mg}$ after four weeks and progressively to $0.11 \mathrm{mg} \mathrm{g}^{-1}$ during the next four weeks (Figure 3). On the other hand, for control samples, TP content was rather regular showing a slight increase from 0.17 to $0.2 \mathrm{mg} \mathrm{g}^{-1}$ fresh weight during five weeks, and then decreased progressively to $0.15 \mathrm{mg} \mathrm{g}^{-1}$ during the last three weeks. Their role in bulb dormancy is unclear, but phenolic compounds seem to inhibit sprouting and low temperature may trigger a signal which could be responsible for the decrease of these compounds, promoting sprout initiation and development. Effect of temperature on total phenolics variation was significant $(P<0.05)$. Close involvement of acid phenolics in sprouting of po-

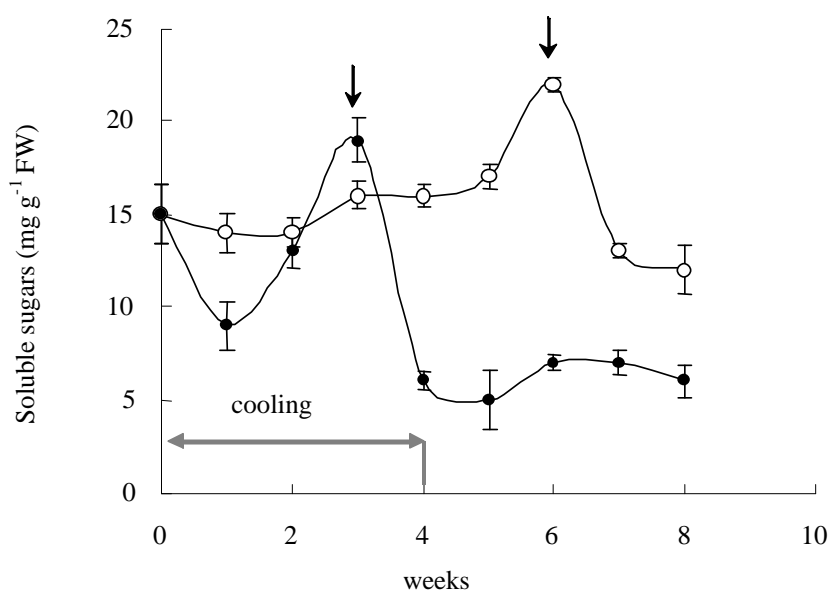

Figure 2 - Soluble sugars (glucose, fructose and sucrose) variation in inner buds of onion bulbs during break of dormancy (• cooled bulbs, o control bulbs) (arrows indicate onset of sprouting and appearance of the first internal green leaves). 
tato buds was reported by Cvirkova et al. (1994). However, this similarity is barely comparable considering the biological and physiological differences between bulbs and tubers.

POD activity of cold treated bulbs indicated a close pattern in relation to the TP variation (Figure 4). POD activity increased slightly from 1.55 to $1.7 \mathrm{U} \mathrm{g}^{-1}$ fresh weight during the first two weeks. Then, POD activity decreased progressively from 1.7 to $1.1 \mathrm{U} \mathrm{g}^{-1}$ during the next three weeks and remained stable during the last three weeks. On the other hand, for control samples, POD activity decreased regularly to $1.1 \mathrm{U} \mathrm{g}^{-1}$ fresh weight along the eight weeks. Low temperature seems to have a similar effect on POD activity by causing a decrease resulting from the signal triggered by cooling. However, statistical analysis showed that cooling was less significant $(P<0.05)$ on POD activity. The role of POD in sprouting of onion is not well established yet, however its role in other vegetables was widely investigated, particularly its degrading activity of IAA, which is considered an effective promoter of sprouting (with cytokinins) (Thomas, 1969).

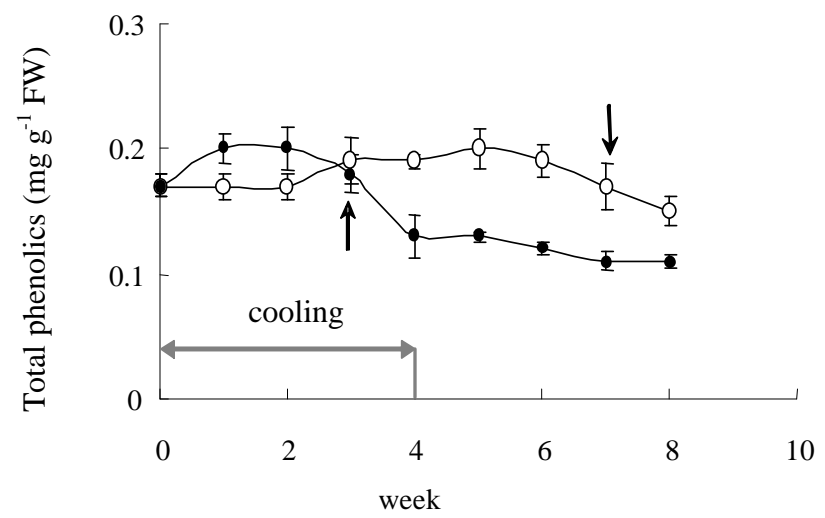

Figure 3 - Variation of total phenolic compounds in inner buds of onion bulbs during break of dormancy $(\bullet$ cooled bulbs, o control bulbs) (arrows indicate onset of sprouting and appearance of the first internal green leaves).

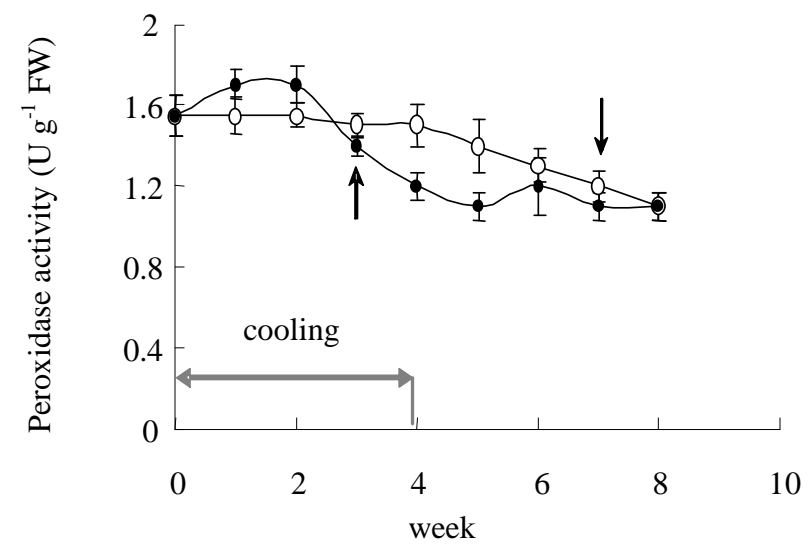

Figure 4 - Variation of peroxidase activity in inner buds of onion bulbs during break of dormancy $(\bullet$ cooled bulbs, o control bulbs) (arrows indicate onset of sprouting and appearance of the first internal green leaves).

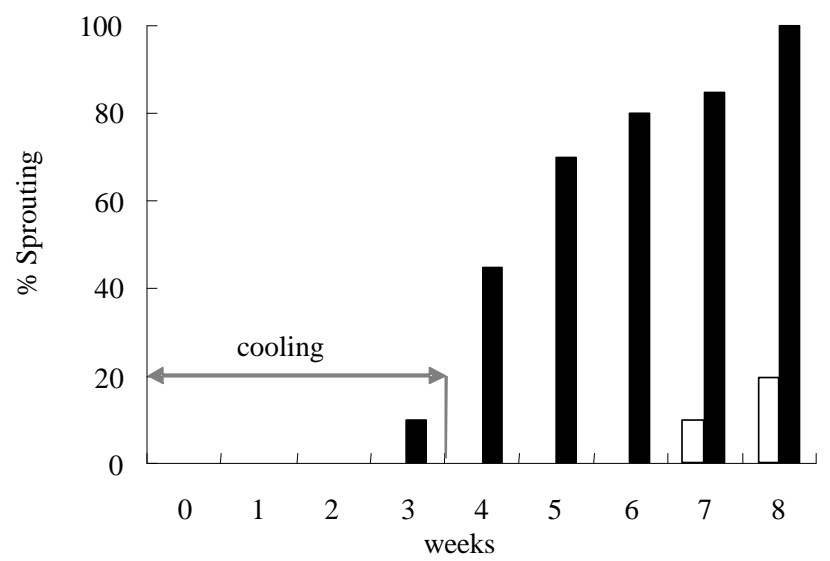

Figure 5 - Effect of low temperature treatment on the break of dormancy of onion bulbs ( $\boldsymbol{\square}$ cooled bulbs, $\square$ control bulbs).

The total breakage of dormancy of cold treated onion bulbs was observed after 8 weeks $(50 \%$ breakage of dormancy was noted between the fourth and fifth week) (Figure 5). In comparison, only $20 \%$ of the control bulbs started sprouting after this period. Cooling had effect $(P<0.05)$ on breakage of dormancy. Statistical analysis of the data also showed effect of sprouting on respiration $\left(\mathrm{O}_{2}\right.$ consumption). The effect of low temperature on the break of dormancy of onion bulbs and other bulbous vegetables was reported previously (Benkeblia, 2003; De Hertogh \& Le Nard, 1993; Komochi, 1990). Although most edible and flower bulbs are sensitive to chilling, others need high temperatures for sprouting (De Hertogh \& Le Nard, 1993; Le Nard, 1982).

Cold treatment at $0^{\circ} \mathrm{C}$ could contribute to induce breakage of dormancy of onion bulbs. These low temperatures also cause a decrease in total phenolics and peroxidase activity. Thus, phenolics and peroxidase seem to be involved in extending the dormancy period of onion bulbs. However, this role seems to have indirect rather than direct involvement in the dormancy process. Consistently with our previous results and other investigations, there is no doubt that cold treatment of "rest organs" induces a signal triggering of biochemical modifications causing breakage of dormancy. A question, however, remains: what is the exact nature of this signal? Current investigation using molecular biology tools may clarify these aspects yet to be studied.

\section{ACKNOWLEDGEMENTS}

To INRA, Avignon (France) for technical assistance, and JSPS (Japan) for partial financial support.

\section{REFERENCES}

ABDALLAH, A.A.; MANN, L.K. Bulb development in the onion (Allium cepa $\mathrm{L}$.) and the effect of storage temperature and bulb rest. Hilgardia, v.35, p.85-112, 1963. 
BENKEBLIA, N. Postharvest technology of onions. In: DRISS, R.; NISKANEN, R.; MOHAN-JAIN, S. (Ed.) Crop management and postharvest handling of horticultural products. Enfield: Science Publishers, 2003. chap.5, p.107-137.

BENKEBLIA, N.; SELSELET-ATTOU, G. Changes in oligosaccharides, phenolics and peroxidase activity in inner bud of onion bulbs during break of dormancy by low temperatures. Acta Agriculturæ Scandinavica, v.49, p.98-102, 1999.

BENKEBLIA, N.; VAROQUAUX, P.; GOUBLE, B.; SELSELET-ATTOU, G. Respiratory parameters of onion bulbs. Effects of irradiation and temperature. Journal of the Science of Food and Agriculture, v.80, p.1772-1778, 2000.

BENKEBLIA, N.; VAROQUAUX, P.; SHIOMI. N.; SAKAI, H. Effect of irradiation, $\mathrm{MH}$ and CIP treatments on respiration rate and oligosaccharides variations in onion bulbs in store. International Journal of Food Science and Technology, v.37, p.169-176, 2002.

BRENES, M.; GARCIA, P.; DURAN, M.C.; GARRIDO, A. Concentration of phenolic compounds changes in storage brines of ripe olives. Journal of Food Science, v.58, p.347-350, 1992.

CVIRKOVA, M.; SUKHOVA, L.; EDER, J.; KORABLEVA, N. Possible involvement of abscissic acid, ethylene and phenolic acids in potato tuber dormancy. Plant Physiology and Biochemmistry, v.32, p.685691, 1994

DE HERTOGH, A.A.; LE NARD, M. Physiology and biochemical aspects of flower bulbs. In: DE HERTOGH, A.A.; LE NARD, M. (Ed.) The physiology of flower bulbs. Amsterdam: Elsevier, 1993. chap.6, p.5369

DENNIS, F.J. Two methods of studying rest: temperature alternation and geneticanalysis. HortScience, v.22, p.820-824, 1987.

GREPPIN, C.; PENEL, C.; GASPAR, T. Molecular and physiological aspects of plant peroxidases. Geneva: Geneva University Press, 1986. 470p.

GÜNES, B.; BAYINDIRLI, B. Peroxidase and lipoxygenase inactivation during blanching of green beans, green peas and carrots. LebensmittelWissenschaft und Technologie, v.26, p.406-410, 1993.
HARBORNE, J.B. Polyphenols. In: MANN, J.; DAVIDSON, R.S.; HARBORNE, J.B. (Ed.) Natural products: their chemistry and biological significance. London: Longmann Scientific \& Technical Press, 1994. chap.8, p.361-388.

HURST, W.C.; SHEWFELT, R.L.; SCHULER, G.A. Shelf-life and quality changes in summer storage onions (Allium cepa). Journal of Food Science, v.50, p.761-763, 1985.

KATO, T. Physiological studies on the bulbing and dormancy of onion plants. VIII: Relation between dormancy and organic constituents of bulbs Journal of the Japanese Society for Horticultural Science, v.3, p.5763, 1966.

KOMOCHI, S. Bulb dormancy and storage physiology. In: RABINOWITCH, H.D.; BREWSTER, J.L. (Ed.) Onions and allied crops. Boca Raton: CRC Press, 1990. v.1, chap.3, p.89-111.

LE NARD, M. Physiology and storage of bulbs: concepts and nature of dormancy. In: LIEBERMAN, M. (Ed.) Postharvest physiology and crop preservation. New York: Plenum Press, 1982. chap.6, p.191-235.

LOOGHEED, E.C.; FRANKLIN, R.C. Air flow influence $\mathrm{CO}_{2}$ production of apple fruits, potato tubers and onion bulbs. HortScience, v.10, p.388390, 1975.

PAK, C.; VAN DER PLAS, L.H.; DE BOER, A.D. Importance of dormancy and sink strength in sprouting of onion Allium cepa. L. during storage. Physiologia Plantarum, v.94, p.277-283, 1995.

RUTHERFORD, P.P. Some biochemical changes in vegetables during storage. Annals of Applied Biology, v.98, p.538-541, 1981.

THOMAS, T.H. The role of growth substances in the regulation of onion bulb dormancy. Journal of Experimental Botany, v.20, p.124-137, 1969.

Received July 31, 2003

Accepted March 15, 2004 